urnal Ilmiah Teunuleh

The International Journal of Social Sciences

Vol. 2, Issue. 1, Mar 2021

E-ISSN: 2746-4393

\title{
THE INFLUENCE OF LEADERSHIP AND WORK MOTIVATION ON THE COMMITMENT OF BANDA ACEH STATE SENIOR HIGH SCHOOL TEACHERS
}

\author{
Akmaluddin ${ }^{1}$ \\ Universitas Bina Bangsa Getsempena \\ akmaluddin@bbg.ac.id \\ Basri $^{2}$ \\ Universitas Jabal Ghafur \\ basri6609@gmail.com \\ Mardhatillah ${ }^{3}$ \\ Universitas Bina Bangsa Getsempena \\ mardhatillah.atjeh@gmail.com
}

\begin{abstract}
This study aims to determine: (1) the influence of leadership on motivation, (2) the influence of leadership on teacher commitment, (3) the effect of motivation on teacher commitment. Influence The study population was all public high school teachers in Banda Aceh City with a total sample of 252 people taken by proportional random sampling, and the data were analyzed using path analysis after calculating the correlation of all research variables in the form of a matrix. The research findings show that the commitment of public high school teachers in Banda Aceh City is directly influenced by the principal's leadership and teacher work motivation. Based on hypothesis testing, it can be concluded: (1) there is a direct influence of leadership on teacher commitment, (2) there is a direct influence of principal's leadership on teacher commitment, (3) there is a direct influence of work motivation on teacher commitment. Suggestions that can be concluded in this study are: (1) the provincial government of Aceh is authorized to produce policies in accordance with the findings in this study (2) for the head of the Aceh education office to improve the quality of policy professionalism directed at the quality of school principals and teacher commitment (3) for school principals to be able to take into account in forming teacher organizational commitment to their schools (4) for teachers to be able to make reference in carrying out their duties as teachers.
\end{abstract}

Keywords: Leadership, Motivation, Teacher Commitment 


\section{A. Introduction}

Improving the quality of education is currently the government's main program to educate the nation. This is as stated in the vision of the Ministry of National Education, namely "Improving Access for Every Citizen to Obtain Quality Education", and is regulated in Aceh Qanun Number 11 of 2014 concerning the Implementation of Education in Aceh Province Chapter III Article 5 paragraphs 1-3 concerning Principles Education Services.

In order to realize quality education in accordance with the vision of the Ministry of National Education and Aceh Qanun Number 11 of 2014, various statutory provisions have been issued, followed by the issuance of Government Regulation of the Republic of Indonesia Number 19 of 2005 concerning National Education Standards (SNP). To realize quality education, the role of the government represented by teachers as the spearhead to carry out the government's mandate in relevance, quality and governance is the main determinant in this case, the emphasis is on teachers in committing to carry out their duties properly and in accordance with the provisions of the law. - the applicable teacher law in Indonesia.

Teachers as implementers of education play an important and strategic role in determining the achievement of learning objectives. Teachers are not only responsible for delivering lessons, but also must be able to create a pleasant learning atmosphere. No matter how good and complete educational facilities and infrastructure, curriculum, media, resources or educational technology are, all of this will mean nothing if it is not accompanied by the commitment of teachers in carrying out their duties in the organization. In working, teachers must have a high sense of responsibility and dedication to the work itself and to the work environment. Teachers will work with a high sense of responsibility and dedication if they have organizational commitment. A person's success in a task assigned to him can be determined by how committed they are to the task and their level of education or knowledge. Without a commitment, the tasks assigned to him will be difficult to carry out properly.

Commitment is a psychological bond of a person as a reflection and feeling of liking for the organization including work involvement, loyalty, loyalty, and feeling of trust in the values of the organization. Basically, carrying out commitments means carrying out obligations, responsibilities, making someone make up their minds, determined, strives, sacrifices, and is responsible for achieving their goals and organizational goals that have been agreed or determined in advance. 
The Influence of Leadership and Work Motivation on The Commitment of Banda Aceh...

Teachers as an important part of the implementation of education must have a high commitment. Commitment is very important because commitment is the most basic thing in carrying out a job. Teachers will find it difficult to carry out their roles and responsibilities as educators if they do not have commitment. The commitment of teachers to school institutions as organizations is basically a condition felt by teachers that can lead to strong positive behavior towards their work organization. Commitment to the organization relates to identification and loyalty to the organization and its goals. A committed teacher will not hesitate to determine his attitude and responsibility for the decisions he makes.

Gultom Syawal, (2009: 10) explains that leadership style also affects the organization's internal management which is described in the form of task structure, authority system and groups from path theory, where the variables of leadership behavior, internal management as external contingency factors and internal characteristics affect organizational outcomes.

The results of Koesmono's research (2007: 13) conclude that the influence of leadership on organizational commitment, agrees with Robbins, that the maturity of leadership effectiveness can encourage and develop organizational commitment to individuals. Meanwhile Newstrom (2006: 215) argues in his theory that leadership has a direct effect on work motivation and indirect effect on job satisfaction, while leadership is influenced by organizational culture.

Lussier (2010: 390) states that leadership is influenced by job satisfaction. Fariana (2015: 1) concludes in his research that the leadership style simultaneously has a significant effect on work motivation. The results of Cahorni's research (2013: 1) show that there is a significant positive effect of leadership style variables which include participatory leadership style, sporty leadership style, directive leadership style, achievement-oriented leadership style on employee motivation.

In addition to leadership factors, teacher work motivation also influences teacher commitment, motivation as a need is dominant, motivation will affect commitment to being a true professional as a pride in a professional association. The model proposed by Colquitt Lepine and Wesson (2009: 5) organizational commitment is influenced by motivational variables. Burton's research (2002: 192) states that employee motivation has a significant positive effect on commitment as measured by three dimensions of commitment, namely affective commitment, normative commitment and continuance commitment. Buraidah's research (2011: 9) shows that the forms of "work motivation 
that have the greatest influence on commitment are responsibility, progress, the work itself, achievements, recognition, administration and school policies, salaries, and interpersonal relationships. Research conducted by Devi (2007: 153) shows that there is a positive influence between motivation and organizational commitment.

\section{B. Method}

The type used in this research is quantitative research with ex post facto research. Path analysis requires the existence of a significant form of linear regression relationship between variables. According to Ridwan (2017: 2) Path analysis is used in analyzing the pattern of relationships between variables with the aim of knowing the direct effect of a set of causal variables (exogenous variables) on a set of effect variables (endogenous variables).

Further explained by Sugiyono (2017: 162) the path analysis model is divided into three types, namely (1) correlated path model (correlation path model); (2) mediated path model (mediation path model); (3) independent path model (free path model). The type of model in this study is the mediated path model. This study analyzes the effect of one variable on other variables, namely: (1) leadership, (2) emotional intelligence (3) job satisfaction, (4) work motivation and (5) teacher commitment.

The population of this study was 108 people and a sample of 84 people who were selected using stratified proportional random sampling to find out specifically how the state of organizational commitment of each stratum

\section{Finding and Discussion}

\section{Finding}

The descriptive findings in this study are as follows:

a. The Leadership Variable of State Senior High School Principals in Banda Aceh City which shows that 1 respondent (0.40\%) is in the high category, 196 respondents $(77.78 \%)$ in the sufficient category, 55 respondents $(21.83 \%)$ in the poor category and not there are respondents (0\%) with low category. Thus, the leadership of public high school principals in Banda Aceh City is generally in the "enough" category.

b. The variable of work motivation of public high school teachers in Banda Aceh shows that 160 respondents (63.49\%) are in the sufficient category, 92 respondents (36.51\%) are in the poor category and there are no respondents (0\%) 
The Influence of Leadership and Work Motivation on The Commitment of Banda Aceh...

in the high and low categories. Thus, the work motivation of public high school teachers in Banda Aceh City is generally in the "enough" category.

c. The variable of Commitment of State Senior High School Teachers in Banda Aceh City shows that 161 respondents (63.89\%) are in the sufficient category, 91 respondents (36.11\%) are in the less category and there are no respondents (0\%) in the high and low categories. Thus, the Organizational Commitment of State Senior High School Teachers in Banda Aceh City is generally in the "enough" category

\section{Discussion}

a. Leadership has a direct positive effect on the Organizational Commitment of SMAN Banda Aceh teachers.

According to the model of Hammer, W. Clay, Schmidt, Fank L, (1977: 312) that "effective leadership is influenced by organizational commitment, organizational knowledge, and interpersonal relationships". Furthermore, the results of Koesmono's research (Koesmono $\mathrm{H}$, Teman, 2007: 13), conclude that there is an influence between leadership on organizational commitment. This also agrees with Robbins who stated that the maturity of leadership effectiveness can encourage and develop organizational commitment to individuals. This is also supported by the findings of Sovyia (Desianty, Sovyia, 2005: 81) which concluded that it was based on regression testing of variables XI and $X 2$ to the $P$ value which resulted in the calculated $F$ value $>F$ table, namely $74,742>$ 3.90420 with a $P$ value of 0.000 ( $P$ value $<0.05$ ), meaning that the variables of transformational leadership and transactional leadership together have a significant influence on organizational commitment.

Colquit at al formulated the Colquitt model that the variables of leadership, ability, character and emotional intelligence affect commitment through job satisfaction, stress, motivation, trust justice \& ethics, learning \& decision making. Leadership is one of the supporting factors that can increase teacher organizational commitment for the better. The process of influencing by the leader to subordinates who are expected to take actions or act through the influence caused by the leader, to achieve the goals set. Efforts to influence subordinates run through a two-party communication process (between leaders and subordinates) that can be done directly or indirectly.

Leaders are people who apply principles and techniques that ensure productivity and work with people, tasks and situations in order to achieve organizational goals, and 
the process of influencing or setting an example to followers through the communication process in an effort to achieve organizational goals. By applying good leadership values, it is expected to be able to increase the organizational commitment of teachers and be able to achieve the goals that have been set. In carrying out his leadership function, the principal must carry out management and coaching through administrative activities in order to influence employees in order to increase their organizational commitment for the better. Thus, efforts that can be made to improve employee performance can be done by increasing the willingness to guide subordinates, giving instructions on the implementation of work, instructing everything related to tasks, improving in designing tasks, and increasing responsibilities. So the changes (high-low) organizational commitment of SMA Negeri teachers in Banda Aceh City can be determined by the level of leadership of the principal.

b. Leadership has a direct positive effect on the work motivation of SMAN Banda Aceh teachers

Leadership has a direct positive effect on the work motivation of State Senior High School teachers in Banda Aceh City, meaning that the better the leadership of the principal will increase the work motivation of the teachers. This is based on hypothesis testing with a path coefficient of $41=0.272$ and $t=4.835$ with a significance level of 0.000 (the hypothesis is accepted if the significance level of tcount $<0.050$ ), so that the direct effect of leadership on work motivation is 0.074 . This coefficient value implies an increase of 1 unit of the leadership variable will increase the work motivation variable by 0.074 units with the assumption that the other variables are considered constant. Furthermore, based on the results of the calculation, the direct influence of leadership on the work motivation of SMA Negeri teachers is $7.4 \%$. This shows that the higher the leadership of the principal of a public high school, it will increase the work motivation of the teachers. Vice versa if the leadership of the principal of a public high school is low, it will reduce the level of work motivation of the teachers.

This research is supported by the theory of John W Newstrom. He argues in his theory that leadership has a direct effect on work motivation (Newstrom, J.W. \& K. Davis. 2006: 215). This is also supported by the research of Nina Fariana (Nina Fariana, 2015: 1) which concludes in her research "leadership style has a significant effect on work motivation simultaneously". Dewi Ratih Cahyorni (Cahyoroni Dewi Ratih, 2009: 2) in her research results also shows that there is a significant positive effect of leadership style variables which include participatory leadership style, supportive leadership style, 
The Influence of Leadership and Work Motivation on The Commitment of Banda Aceh...

directive leadership style, achievement-oriented leadership style on work motivation in employees.

The findings of this study are in line with the theory proposed by Gibson, Ivancevich and Donelly (2006) which explains that a leader tries to use his influence to motivate individuals to achieve the same goal. This can be interpreted that leadership as a process of influencing others to achieve results in accordance with organizational goals. The process of influencing by the leader to subordinates who are expected to take actions or act through the influence caused by the leader, to achieve the goals set. Efforts to influence subordinates run through a two-party communication process (between leaders and subordinates) that can be done directly or indirectly.

The leader is a person who has skills and advantages in one area, so that he is able to influence other people or groups to jointly carry out certain activities, for the achievement of one or more goals in certain situations. field) does not force employees to perform tasks according to their will, but plays a role in inviting and guiding members (employees) as their subordinates. Increased leadership is needed to increase employee motivation.

Robins and Coulter $(2007 ; 152)$ state that motivation is the willingness to make a high level of effort to achieve organizational goals, which is conditioned by the ability of the effort to satisfy the needs of a number of individuals. Activities influence people so that they will work together to achieve desired goals. Leadership effectiveness is measured by output factors and human factors. The output factor is the level of results achieved by the work unit which is how well the targets have been planned, which include productivity, quality and efficiency. The human factor shows the level of cooperation among employees and job satisfaction in the institution where they work.

Leaders can be an inspiration to their subordinates so that they are encouraged and motivated to move forward in improving good and continuous results in accordance with the organizational vision adopted. Thus, to increase the work motivation of employees, it is necessary to increase the value of leadership, so that it can increase all dimensions of leadership which include piety, honesty, intelligence, sincerity, simplicity, breadth of view, commitment, expertise, openness, breadth of social relations, maturity and justice, confidence, and initiative. So the changes (highs and lows) of the work motivation of public high school teachers in Banda Aceh City can be determined by the high and low leadership of the principal. 


\section{c. Work Motivation has a direct positive effect on the Organizational Commitment of SMAN Banda Aceh teachers}

Work motivation has a direct positive effect on the organizational commitment of State Senior High School teachers in Banda Aceh City, meaning that if the work motivation of teachers is getting better, it will increase teacher organizational commitment. This is based on hypothesis testing with a path coefficient of $54=0.381$ and $t=6.449$ with a significance level of 0.000 (the hypothesis is accepted if the significance level of tcount <0.050), so that the direct effect of work motivation on employee performance is 0.145 . This coefficient value implies an increase of 1 unit of work motivation variable will increase the teacher's organizational commitment variable by 0.145 units assuming the other variables are considered constant. Based on the path coefficient value obtained in sub structure 3 , it can be concluded that the influence of work motivation variable on organizational commitment is in the top position when compared to other exogenous variables (leadership, emotional intelligence, and job satisfaction). Furthermore, based on the calculation results, the total direct effect of work motivation on teacher organizational commitment is $14.5 \%$. This shows that the higher the work motivation of teachers, the higher their organizational commitment. Likewise, if the work motivation of teachers is low, it will reduce the level of organizational commitment.

This research is supported by the model proposed by Colquitt at al (2009: 5), where organizational commitment is influenced by motivational variables. Burton, et al (2002: 192), stated that employee motivation has a significant positive effect on commitment as measured by three dimensions of commitment, namely affective commitment, normative commitment and continuous commitment. This is also supported by research by Buraidah (2011: 9) which shows that the forms of work motivation that have the greatest influence on commitment are responsibility, progress, the work itself, achievements, recognition, administration and school policies, salaries. and interpersonal relationships.

Motivation as a need is dominant. Motivation will affect the commitment to become a true professional and as a pride in a professional association. Someone who already has motivation means that he already has the power to get success in life. Teachers who have high motivation will have strong discipline against the rules that have been made. Obedience to the rules that have been made can be seen from the implementation of tasks wholeheartedly, being present on time, caring for the place of 
The Influence of Leadership and Work Motivation on The Commitment of Banda Aceh...

work, having high work loyalty and being responsible for work. With motivation, there will be an impulse within a person, whether consciously or not, to take action with a specific goal.

Work motivation is an impulse that grows within a person, both from within and outside himself to do a job with high enthusiasm using all the abilities and skills he has which aims to get work results so as to achieve satisfaction in accordance with his wishes. To be able to provide quality and quantity work, a teacher employee needs work motivation within him which will affect his work spirit so as to improve his performance.

Various efforts are made by humans, of course, to fulfill their wants and needs, but so that their desires and needs can be fulfilled, they cannot be obtained without maximum effort. Given the needs of one person with another, of course, the way to get it will be different. In meeting their needs, a person will behave according to the impulses they have and what underlies their behavior, for that it can be said that within a person there is a force that leads to his actions.

Organizational commitment is the strength of employee involvement in an organization, if employees are involved in problems in the organization, employees will automatically be motivated to help the success of the organization. Organizational commitment reflects employee loyalty to the organization and an ongoing process in which members of the organization express their concern for the organization and the continuous success and progress of this reflection as an activity indicates that employees are actively motivated and will have a commitment to the organization. To increase organizational commitment through work motivation, it can be done with the desire to be superior, including the desire to excel at work and the desire to be the best; wants a challenging job such as likes challenges and has a great desire to achieve targets; building cooperation includes being able to work together, communicate and work in teamwork; the existence of self-esteem for employees includes self-appreciation and recognition; and career rewards that include advancement opportunities and additional income. So the changes (high and low) organizational commitment of public SMA teachers in Banda Aceh City can be determined by the high and low work motivation of State Senior High School teachers in Banda Aceh City.

\section{Conclusion}

Principal leadership has a direct positive effect on the commitment of public high school teachers in Banda Aceh City. Leadership is manifested by indicators of having the 
ability to influence subordinates to achieve organizational goals, directing subordinates not to run away from organizational goals, fostering subordinates in accordance with the rules that apply to the organization and regulating or moving subordinates who do not carry out their duties as members of the organization, leaders who have creativity in carrying out their duties. duties and functions as the leader of the school organization. This indicates that the higher or better the leadership of the principal, the higher the organizational commitment of public high school teachers in Banda Aceh City.

Principal leadership has a direct positive effect on the work motivation of State Senior High School teachers in Banda Aceh City. Leadership is manifested by indicators, namely having the ability to influence subordinates to achieve organizational goals, directing subordinates not to run away from organizational goals, fostering subordinates in accordance with applicable rules in the organization and regulating or moving subordinates who do not carry out their duties as members of the organization, leaders who have creativity in carry out their duties and functions as the leader of the school organization. This indicates that the higher or better the leadership of the principal, the higher the motivation of public high school teachers in Banda Aceh City.

Teacher work motivation has a direct positive effect on the commitment of State Senior High School teachers in Banda Aceh City. Work motivation is manifested by indicators, namely having high enthusiasm in doing tasks, being willing to do work in the organization even outside the predetermined working hours, having enthusiasm in carrying out organizational tasks, having persistence in doing the work assigned by the organization and rewarding a career which includes advancement opportunities and additional income. This indicates that the higher or better the work motivation of teachers, the higher the commitment of public high school teachers in Banda Aceh City.

\section{Bibliography}

Buraidah, (2011). "Pengaruh Kompensasi Dan Motivasi Terhadap Komitmenorganisasi Di Organisasi Pendidikan Islam". (Pascasarjana Psikologi, Universitas Gunadarma

Burton, J.P., T.W. Lee dan B.C. Holtom. (2002). The Influence Of Motivation To Attend, Ability To Atted And Organizational Commitment On Different Types Of Absence Abhavior" Jurnal of Managgerial Issues, Summer: 181-197

Cahyoroni Dewi Ratih, (2009). Pengaruh Gaya Kepemimpinan Terhadap Motivasi Kerja Karyawan (Studi Pada Karyawan Pdam Kota Batu), Fakultas Ekonomi UM 
The Influence of Leadership and Work Motivation on The Commitment of Banda Aceh...

Colquitt, Jason A., Jeffery A. Lepine and Michael j Wesson, (2009). Organizational Behavior Imformance And Commitment In The Workplace, New York: McGraw-Hill Irwin

Devi, E.K.D. (2007). “Analisis Pengaruh Kepuasan Kerja Dan Motivasi Kerja Terhadap Kinerja Karyawan Dengan Komitmen Organisasional Sebagai Variabel Intervening Studi pada Karyawan out Sourcing PT. Semaru Karya Buana. Semarang: Universitas Diponegoro, Tesis

Gibson, James L, dkk, (1996). Organisasi , Prilaku, Struktur, Proses. Jakarta: Bina Rupa Aksara

Gultom Syawal, (2009), KEBERLANJUTAN PROGRAM STUDI Kajian Pengaruh Kepemimpinan, Atmosfir Akademik, Manajemen Internal dan Produktivitas Terhadap Keberlanjutan Program Study Di Universitas Negeri Medan. Program Pasca Sarjana Universitas Negeri Jakarta

Hammer, W. Clay, Schmidt, Fank L, (1977). Contem Problem In Personal, Chicago: ST Clair Press

Jhon W Newstrom, (2006). Organizational Behavior: Human Behavior At Work ( $9^{\text {th }}$ Ed) New York: McGraw Hill

Koesmono H, dkk, (2007). Pengaruh Pimpinan dan Tuntunan Tugas Terhadap Komitmen Organisasi Dengan Variabel Moderasi Motivasi, Diponegoro: Universitas Khatolok Widya Mandala

Lussier, Robert N. and F. Achua, Christopher, (2010) Leadership : Theory, Application, and Skill Development, $4^{\text {th }}$ Edition (Mason, Ohio : South-Western Cengage Learning.

Ridwan, (2012). Cara Menggunakan dan Memakai Path Analysis (Analisis Jalur), Bandung: Alfabeta

Ridwan, Engkos Achmad Kuncoro, (2017). Path Analisis Cara Menggunkan Dan Memaknai, Bandung: Alfabeta

Robins, S Millet, B. Waters-Mars, T, (2007). Organizational Behavior. Fith Edition Frennchs Forest: Person Education Australia. 